\title{
Robert S. Wistrich and European Jewish History: Straddling the Public and Scholarly Spheres*
}

\author{
Michael Berkowitz \\ University College London
}

Robert S. Wistrich, the Neuberger Professor in Modern Jewish History at the Hebrew University of Jerusalem, can hardly be considered a senior scholar for whom the major part of his work is behind him. Yet the sheer amount and range of his writing would be staggering even if he had been active in the historical profession since World War II. It may come as a surprise to learn that he was born in the Soviet Union in 1945. Among the post-Second World War generation of scholars, Wistrich, who was raised and educated in Great Britain-albeit with formative stays at Stanford and Jerusalem-is truly an extraordinary figure. He has written nine books (and counting) and edited four others (and counting); he was also a lead adviser for two documentary film projects which were broadcast internationally. Scholars of Central European history and modern Jewish history could not fail to notice Wistrich's tremendous output. Obviously there is some overlap in his books and articles; but, given the quantity of his work, the areas of repetition are not nearly as plentiful as one might expect.

Wistrich should be noted, as well, for having embraced the role of public intellectual to a much greater degree than have many in his cohort, even in the context of Israeli society, where academics are less foreign to political debates than in the

* The following works by Robert S. Wistrich are considered in this article: Revolutionary Jews from Marx to Trotsky (London, 1976); Trotsky: Fate of a Revolutionary (New York: Barnes \& Noble, 1976); The Left against Zion: Communism, Israel, and the Middle East (London: Vallentine, Mitchell, 1979); Who's Who in Nazi Germany (New York: Macmillan, 1982); Socialism and the Jews: The Dilemmas of Assimilation in Germany and Austria-Hungary (Rutherford, N.J.: Fairleigh Dickinson University Press, 1982); Hitler's Apocalypse: Jews and the Nazi Legacy (New York: St. Martin's, 1985); The Jews of Vienna in the Age of Franz Joseph (Oxford: Oxford University Press, 1989); (ed.) Anti-Zionism and Antisemitism in the Contemporary World (New York: New York University Press, 1990); Between Redemption and Perdition: Modern Anti-Semitism and Jewish Identity (London and Boston: Routledge, 1990); Antisemitism: The Longest Hatred (London: Thames Metheun, 1991); (ed.) Austrians and Jews in the Twentieth Century: From Franz Joseph to Waldheim (New York: St. Martin's, 1992); Weekend in Munich: Art, Propaganda and Terror in the Third Reich (London: Pavilion, 1995); (ed.) Terms of Survival: The Jewish World since 1945 (London and New York: Routledge, 1995); and Robert S. Wistrich and David Ohana, eds., The Shaping of Israeli Identity: Myth, Memory, and Trauma (London and Portland, Oreg.: Frank Cass, 1995; first a special issue of Israel Affairs). Both Wistrich's book The Limits of Fraternity (Oxford: Littman Library of Jewish Civilization, 1997) and his controversial review in Commentary (February 1998) of Albert S. Lindeman's Esau's Tears (Cambridge, 1997) appeared while this essay was in press.

[The Journal of Modern History 70 (March 1998): 119-136]

(C) 1998 by The University of Chicago. 0022-2801/98/7001-0005 $\$ 02.00$

All rights reserved. 
United States. The recent imbroglios surrounding Zeev Sternhell's Binyan umah o tikun hevrah? Leumit ve-sotsyalizm bi-tenu'at ha-avodah ha-Yisre'elit: 1904-1940 (Nation building or a new society? Socialist-nationalism and the Israeli Labor Movement) and Moshe Zimmermann's unflattering comparison of Jewish settlers' children in Hevron to Hitlerjugend offer ample proof of Israeli scholars' visibility, if not chutzpah, in public debates. ${ }^{1}$ Wistrich has not been party to any great controversy, but this should not be read as a failure of nerve or lack of backbone. In speeches and writings in Israel, Europe, and the United States, he has argued forcefully on issues such as the demographic challenges facing modern Jewry, the role of Jews on the contemporary European political stage, and the position of the State of Israel vis-a-vis the Arab world and Islamic fundamentalism. One of his most fascinating books, Between Redemption and Perdition: Modern Anti-Semitism and Jewish Identity, is based on public lectures given over a fifteen-year period; it is no slim volume. Any evaluation of the whole of Wistrich's work will necessarily be colored by one's perspective on historians' attempts "to address themselves to the laity." Detailing the sorry state of the historical discipline in the United States in the late 1980s, Peter Novick observed in That Noble Dream that "Within the profession one looked in vain for successors to the generation of Handlin, Hofstadter, and Woodward, who had had at least some success in reaching out to the educated nonprofessional. With the exception of a few problematic ventures in public history, professional historians' audience was more than ever confined to each other, plus a dwindling student constituency." 2

In the light of this phenomenon in America, and to a lesser extent in most of the academic world, Wistrich must be credited with a valiant effort to engage a broad public in his scholarly pursuits. It is important, as well, to remember that teaching Jewish history at the Hebrew University of Jerusalem is in many respects unlike teaching United States history at Harvard, British history at Oxford, or French history at the Sorbonne. Wistrich, as a leading member of Hebrew University's Institute of Contemporary Jewry, is heir to a loosely defined tradition of "Jerusalem scholars" stemming from the university's Institute of Jewish Studies, which, "in fusing public and scholarly functions" encouraged its faculty "to edify a wide readership and to foster a strong sense of national identity." ${ }^{3}$ Furthermore, his recent

\footnotetext{
${ }^{1}$ See Zeev Sternhell, Binyan umah o tikun hevrah? Leumit ve-sotsyalizm bi-tenu'at ha-avodah haYisre'elit: 1904-1940 (Nation-building or a new society? Socialist-nationalism and the Israeli Labor Movement, 1904-1940) (Tel Aviv, 1995); and Menahem Brinker, "Bilti maspik be-universaliyut" (Failing grade in universalism), Ha-Aretz (July 5, 1995), "Sefarim" sec., pp. 1, 14. See also Baruch Kimmerling, "Yeladim shel buah rayunit" (Children in an ideological bubble), Ha-Aretz (May 19, 1995), sec. B, p. 7; Jacob Dallal, "Hebrew U. Won't Take Action against Zimmerman," Jerusalem Post (May 1, 1995), p. 2. There are a number of notable examples: in his controversial best-seller, Tom Segev writes that the research of George Mosse was explicitly used in a 1983 Knesset debate on the lessons of the Holocaust; see Tom Segev, The Seventh Million: The Israelis and the Holocaust, trans. Haim Watzman (New York, 1993), p. 403. See also Yehoshafat Harkabi, The Bar Kokhba Syndrome: Risk and Realism in International Politics, ed. David Altschuler, trans. Max D. Ticktin (Chappaqua, N.Y., 1983).

${ }^{2}$ Peter Novick, That Noble Dream: The “Objectivity Question” and the American Historical Profession (New York, 1993), p. 577.

${ }^{3}$ David N. Myers, Reinventing the Jewish Past: European-Jewish Intellectuals and the Zionist Return to History (New York, 1995), pp. 87, 137.
} 
work focusing on the messianic aspect of Theodor Herzl's appeal to fin-de-siecle Jewry is continuous with the efforts of his predecessors, Ben-Zion Dinaburg and Gershom Scholem. In a brilliant analysis of the development of this "loose field" of Judaica scholars, David N. Myers writes that "Scholem regarded Zionism as a realistic alternative to the folly of messianic activism and the passivity of traditional messianic belief" while "Dinaburg retained the category of messianism to explain both proto-Zionist and Zionist activity." 4 In availing himself of the methodologies of the new history, Wistrich is in the midst of a synthesis of these approaches in probing Herzl's reception as a messianic figure in Jewish life and politics. $^{5}$

To be sure, other historians of Central Europe and modern Jewry have not, as a rule, shied away from public forums; but the frequency of Wistrich's forays, as well as the intensity of his commitment to the day's events - often tied to the ongoing fortunes and misfortunes of Jewry - places him in a category with Tony Judt (who also happens to be unusually prolific) and few others. ${ }^{6}$ It is interesting that, although both Wistrich and Judt have appeared in the Times Literary Supplement, Judt tends to situate himself — in terms of Jewish public intellectualism — amid the crowd of the left-liberal journal Tikkun, while Wistrich is found in the pages of the "neo-conservative" Commentary, well to the right of the secular-Jewish political spectrum. Without mentioning him specifically, Wistrich seems to be the kind of scholar Theodore Hamerow had in mind when he demanded in his Reflections on History and Historians that historians should speak to a public beyond academe. ${ }^{7}$ There is no doubt, though, that Hamerow would be queasy about Wistrich's intentional merger of politics and scholarship. Although it is always a thorny issue in historiography, Wistrich is more transparent than others about the relationship between his academic work and his political views. But he does not adhere to a predictable line as delineated by Commentary or any specific Israeli or Diaspora political camp: he diverges from the path of American Jewish neoconservatives in their heightened suspicions over Israel's engagement in the Oslo II peace process, and he questions the neoconservatives' vague pessimism regarding the possibilities of secular-Jewish cultural renewal. In the introduction to his recent edited work, Terms of Survival: The Jewish World since 1945, he asserts that the

Jews are a people with an uncommon sense of vocation and purpose, a messianic belief in the validity of their own tradition and their monotheistic uniqueness. Living under siege is not the goal of their existence nor is a state of estrangement from the world ultimately conducive to the flourishing of their culture. It may well be that we are now

\footnotetext{
${ }^{4}$ Ibid., p. 146.

${ }^{5}$ Robert S. Wistrich, “Theodor Herzl: The Making of a Political Messiah,” in The Shaping of Israeli Identity: Myth, Memory, and Trauma, ed. Robert S. Wistrich and David Ohana (London and Portland, Oreg., 1995; first a special issue of Israel Affairs), pp. 1-37.

${ }^{6}$ See Tony Judt, Marxism and the French Left: Studies on Labour and Politics in France, 1830 1981 (Oxford, 1986), Past Imperfect: French Intellectuals, 1944-1956 (Berkeley and Los Angeles, 1992), and La reconstruction du parti socialiste: 1921-1926 (Paris, 1976); Tony Judt, ed., Resistance and Revolution in Mediterranean Europe, 1939-1948 (London, 1989); and Tony Judt, Socialism in Provence, 1871-1914: A Study in the Origins of the Modern French Left (Cambridge, 1979).

${ }^{7}$ Robert S. Wistrich, Reflections on History and Historians (Madison, Wis. 1987).
} 
moving into a new historical era when this will no longer be the dominant mode of Jewish existence for the majority of the Jewish people. An Israel at peace with its neighbours at the dawn of the twenty-first century would be a mighty step in this direction. The democratization of Russia and its integration into the world economy would be another. The strengthening of bonds in a prosperous, tolerant, pluralistic European Union and the maintenance of a powerful, democratic America would be further guarantees for the freedom and security of Jewish existence. But the survival of a meaningful Jewish identity in the Diaspora ultimately depends on the Jews themselves. Freedom, equality, wealth and empowerment cannot in themselves ensure the content of Jewish life, its quality and transmissibility to future generations. This in turn depends on Jewish education, Jewish commitment and preserving an ancient Jewish conviction-that the golden age of Judaism still lies in the future. ${ }^{8}$

Wistrich distances himself from the devotees of "Jabotinskian revisionism" who hold that an "'iron wall' of Jewish power" is elemental to any possibility of an ongoing, vibrant Jewish life in its ancestral homeland. ${ }^{9}$ The programmatic statement above is rather atypical for a scholar of modern Jewry, particularly one who has not had a rabbinical career on the pulpit as well as in the university. Such a prescription would not be so noteworthy coming from a commentator like Arthur Hertzberg, who has maintained footholds in both the scholarly and the publicintellectual worlds, as a professor, a congregational rabbi, and president of a major Jewish organization. ${ }^{10}$ Perhaps the historian who comes closest to Wistrich in terms of the outpouring of scholarship, and who is politically more akin to him than Hertzberg and Judt, is Walter Laqueur. Laqueur, like Wistrich a passionate cold warrior and defender of Israel, has even turned to writing autobiography and novels. ${ }^{11}$ Laqueur, too, has written considerably for lay audiences, and for many of the same conservative journals to which Wistrich has contributed; but he does not seem to share Wistrich's zeal for addressing the general public, in person. Maybe this is because Laqueur has been more a denizen of thinktanks than has Wistrich.

Obviously Wistrich aspires to reach a popular audience, and he has achieved this to some extent. Yet he has never received the kind of popular affection that

\footnotetext{
${ }^{8}$ Robert S. Wistrich, ed., Terms of Survival: The Jewish World since 1945 (London and New York, 1995), p. 9.

${ }_{9}^{9}$ See Robert S. Wistrich, Hitler's Apocalypse: Jews and the Nazi Legacy (New York, 1985), p. 252; cf. David Vital, The Future of the Jews (Cambridge, Mass., 1990).

${ }^{10}$ See Arthur Hertzberg, Jewish Polemics (New York, 1992), Being Jewish in America: The Modern Experience (New York, 1979), The French Enlightenment and the Jews (New York, 1968), The Jews in America: Four Centuries of an Uneasy Encounter (New York, 1989), and The Zionist Idea: A Historical Analysis and Reader (New York, 1971).

${ }^{11}$ For his publications up to 1985, see Walter Laqueur: A Bibliography of His Work: With an Appreciation by Amos A. Jordan and a Response by Walter Laqueur (Washington, D.C., 1986); his later works include Walter Laqueur, The Age of Terrorism (Boston, 1987), Black Hundred: The Rise of the Extreme Right in Russia (New York, 1993), The Dream That Failed: Reflections on the Soviet Union (New York, 1994), The Political Psychology of Appeasement: Finlandization and Other Unpopular Essays (New Brunswick, N.J., 1988), Soviet Realities: Culture and Politics from Stalin to Gorbachev (New Brunswick, N.J., 1990), Stalin: The Glasnost Revelations (New York, 1990), and Thursday's Child Has Far to Go: A Memoir of the Journeying Years (New York, 1992); see also Jehuda Reinharz and George L. Mosse, eds., The Impact of Western Nationalisms: Essays Dedicated to Walter Z. Laqueur on the Occasion of His Seventieth Birthday (Newbury Park, Calif., 1992).
} 
Irving Howe attained through his monumental World of Our Fathers. ${ }^{12}$ It may be that those who would most welcome Wistrich's opus do not exist: the sons and daughters of the fathers he writes of, in Vienna and elsewhere, did not "make it" but in great measure perished in the Holocaust. His work details the tragically arrested development of Jewish communal life and politics in Central and Western Europe, the continuity of which was utterly shattered. If Christian Europe had had the sense of Hugo Bettauer's Austrians in his chilling fantasy, Die Stadt ohne Juden, in which the non-Jews of interwar Europe realize they have made a horrible mistake by persecuting and expelling their Jews, ${ }^{13}$ Wistrich might be the European Jewish equivalent of a Stephen Birmingham or Irving Howe. ${ }^{14}$ Sadly, there are few European spaces of public discourse where names like Adolf Fischof and Moritz Guedemann have much resonance, where Wistrich might be Salonfaehig.

This review essay does not purport to be a comprehensive treatment of the Wistrich oeuvre, nor does it intend to assess thoroughly each of Wistrich's contributions. Admittedly it will not do justice to Wistrich's volumes consisting primarily of essays by other scholars - despite the fact that he contributes a substantial article in each and clearly leaves his imprint on the character of the respective collections. Suffice it to say that in The Shaping of Israeli Identity, Terms of Survival, Austrians and Jews in the Twentieth Century, Anti-Zionism and Antisemitism in the Contemporary World, and The Left against Zion: Communism, Israel and the Middle East Wistrich evinces a genuine generosity toward several scholars with whom he has disagreed, and he welcomes interdisciplinary breadth. In sum, these books are far too rich and varied to be treated briefly. Instead, my goal here is to illuminate some of the central problems Wistrich has addressed as author (as opposed to his roles as a book and journal editor) and to comment more generally about the significance of his work in the context of modern European and modern Jewish history. As much as Wistrich is a very important scholar without whom the community of historians would be greatly impoverished, much of his work fits into discernible patterns of the historiography of modern Jewry, Central Europe, and antisemitism. In other words, he examines Jews in much the same way other historians of Jewry have looked at the Judenfrage, ${ }^{15}$ and he explores the phenomenon of antisemitism with much the same lenses that have been used by others. In part, his difference in approach, depending on his subject, seems implicitly determined by both his main

${ }^{12}$ Irving Howe, World of Our Fathers (New York, 1976), and A Critic's Notebook, ed. and intro. Nicholas Howe (New York, 1994). Irving Howe also wrote a biography of Trotsky, Trotsky (New York, 1978).

${ }^{13}$ Hugo Bettauer, Die Stadt ohne Juden (Hannover, 1922); English trans., City without Jews, trans. Salomea Neumark Brainin (New York, 1936); see also Murray G. Hall, Der Fall Bettauer (Vienna, 1978); and Michael Brenner, The Renaissance of Jewish Culture in Weimar Germany (London and New Haven, Conn., 1995), pp. 131-32. It is interesting that Bettauer's novel, its German literary remake (Artur Landsberger, Berlin ohne Juden [Hannover, 1925]), and the film, which had some impact in Germany, have not been used by Wistrich.

${ }^{14}$ See Stephen Birmingham, "Our Crowd": The Great Jewish Families of New York (New York, 1967), "The Rest of Us”: The Rise of America's Eastern European Jews (Boston, 1984), and The Grandees: America's Sephardic Elite (New York, 1971).

${ }^{15}$ See Paula Hyman, "The History of European Jewry: Recent Trends in the Literature," Journal of Modern History 54, no. 2 (June 1982): 303-19. 
subject and the broad audience he intends to reach. In dealing with Jews, he assumes that Jews tended to see the world and operate from a predominantly rational perspective. In delving into the Weltanschauung and activities of antisemites and anti-Zionists, he presupposes that opponents of the Jews are motivated, to a substantial degree, by irrational forces and a symbol-laden environment. We shall return to this dichotomy as one of the cardinal features of his scholarship.

Two of his books fall clearly in the domain of reference texts: Who's Who in Nazi Germany and Antisemitism: The Longest Hatred. ${ }^{16}$ The "objective" of Wistrich's directory "is to provide a reliable and stimulating source of information and reference for serious students and for the interested lay reader concerning what is a pivotal period in twentieth century European history. The book is arranged as a collection of compact, succinct biographies listed in alphabetical order and giving basic information about the careers of nearly 350 individuals who were prominent or significant in the Third Reich" (p. 1). One of the many strengths of the book is its reasonable contextualization: for example, despite the great publicity accorded Adolf Eichmann on his capture by Israeli agents and his trial in Jerusalem, Eichmann receives less than two pages; Himmler, five; and Hitler, eight. Wistrich's compendium deserves to be included among the more authoritative reference works on Nazi Germany and the Holocaust, such as Michael Marrus's superb The Holocaust in History, Milan Hauner's day-by-day breakdown of Hitler's career, Hitler: A Chronology of His Life and Time, and Peter Stachura's terse summary of the secondary literature in the field, The Weimar Era and Hitler, 1918-1933: A Critical Bibliography. ${ }^{17}$

Wistrich's Antisemitism: The Longest Hatred, was written "to accompany the Thames Television series on antisemitism" of the same name with which the author was "closely associated as historical adviser" (p. xi). This book "is a highly condensed and concentrated version" of his extensive research on antisemitism, culled from over a dozen archives on three continents, "aimed at the interested general reader without encumbering him or her with an unnecessarily massive scholarly apparatus or an overly dry, academic approach" (p. xii). To Wistrich's credit,Antisemitism does not begin and end with the Nazis, although the Holocaust remains of paramount concern. Wistrich shows how the Holocaust was different from all other anti-Jewish persecutions which came before and after; yet the form of the book might lead some readers to see the Nazi years as the darkest chapter in the larger story of eternal antisemitism. The latter segments of this work, along with Wistrich's more in-depth examinations of Arab antisemitism and antisemitism in the postwar Communist countries, probably will have the shortest shelf life of his scholarship, coming to be regarded as period pieces in contrast to his more durable scholarly endeavors. What seems to be missing from his largely informative account of the legacy of Nazi antisemitism in Eastern Europe, and of antisemitism

\footnotetext{
${ }^{16}$ Robert S. Wistrich, Who's Who in Nazi Germany (New York, 1982), and Antisemitism: The Longest Hatred (London, 1991). Page references to these works are cited parenthetically in the text.

${ }^{17}$ Michael Marrus, The Holocaust in History (Hanover, N.H., 1987); Milan Hauner, Hitler: A Chronology of His Life and Time (New York, 1983); Peter Stachura, The Weimar Era and Hitler, 1918-1933: A Critical Bibliography (Oxford, 1977).
} 
in Arab and Islamic societies, is a sensitivity to the problem of agency: Who is making these arguments? In these cultures where political manifestos are largely produced by a state apparatus, Wistrich does not confront the questions of the extent to which such sentiments represent popular opinion, or how one can gauge such attempts to mold public attitudes. There are some other minor caveats for those intending to use Antisemitism as the basis for further research or as a teaching tool. Although his biography is necessarily "Select," there are some curious omissions, such as the seminal works of George Mosse and Shulamit Volkov's essay on antisemitism as a "cultural code." 18 The final chapters of two recent books, The People Speak! Anti-Semitism and Emancipation in Nineteenth Century Bavaria by James F. Harris and Ordinary Men: Reserve Police Battalion 101 and the Final Solution in Poland by Christopher Browning, contain excellent interpretations of recent work on antisemitism, and Richard Levy has produced a helpful anthology. ${ }^{19}$

In addition to contributing to the history of antisemitism, Wistrich is a principal scholar of the Jew's encounter with socialism and communism. His first book, Revolutionary Jews from Marx to Trotsky, focuses on "the psychological challenge which the Jewish problem posed to revolutionaries and Socialists of Jewish origin." The connecting thread, Wistrich found, was that "in spite of all national and social divergencies, Jewish revolutionaries ... tended to display a remarkable similarity in their assessments of the Jewish problem, which in my view reflected their own incomplete, subjective emancipation." In his preface Wistrich makes no attempt to camouflage his antipathy for the communist system into which he was born, the Soviet Union, and its harm to its Jews: "If Moses, according to Jewish tradition, led the Children of Israel out of slavery into freedom, then Communism by a strange twist of fate led them back into bondage. In Soviet Russia the 'Promised Land' turned out to be a twentieth-century 'Egypt.' Hence, it is not surprising that the Jews should be looking to their own heritage for spiritual sustenance and survival."

Contrary to what might be expected to follow from the author's dogmatic preface, in which he also states that socialism and communism always, and inevitably, led to a blind alley for Jews, his ten vignettes - of Marx, Lassalle, Eduard Bernstein, Rosa Luxemburg, Victor Adler, Otto Bauer, Bernard Lazare, Leon Blum, Julius Martov, and Trotsky - are far less wooden than promised. In part, Wistrich seemed determined to strip the notion of "The Non-Jewish Jew," as articulated by Trotsky's great admirer, Isaac Deutscher, of its romantic grandeur. ${ }^{20}$ The only way

\footnotetext{
${ }^{18}$ George Mosse, The Crisis of German Ideology (New York, 1964), and Toward the Final Solution (New York, 1978); Shulamit Volkov, "Antisemitism as a Cultural Code: Reflections on the History and Historiography of Antisemitism in Imperial Germany," Leo Baeck Institute Year Book 23 (1978): 25-46.

${ }^{19}$ James F. Harris, The People Speak! Anti-Semitism and Emancipation in Nineteenth Century Bavania (Ann Arbor, Mich., 1994), pp. 209-31; Christopher Browning, Ordinary Men: Research Police Battalion 101 and the Final Solution (New York, 1993), pp. 159-89; Richard S. Levy, ed., Antisemitism in the Modern World: An Anthology of Texts (Lexington, Mass., and Toronto, 1991).

${ }^{20}$ See Isaac Deutscher, The Prophet Armed: Trotsky, 1879-1921 (New York, 1954), The Prophet Unarmed: Trotsky, 1921-1929 (New York, 1959), The Prophet Outcast: Trotsky, 1929-1940 (New York, 1963), and The Non-Jewish Jew and Other Essays, ed. Tamara Deutscher (London and New York, 1968).
} 
to be politically effective, according to Wistrich, is to be a manifestly Jewish Jew. Wistrich's second book, on Trotsky, clearly grew out of his desire to debunk further what he saw as the Deutscher-created mythical Trotsky. This volume on Trotsky, however, did not seem to have a very strong impact on the historiography of the Russian Revolution and early Soviet period, which is now being written with the benefit of an infinitely richer storehouse of archival materials. ${ }^{21}$ None of Wistrich's works are cited in Erich Haberer's excellent Jews and Revolution in Nineteenth Century Russia, which seeks to probe the relationship between Jewry and the formative period of socialism. Haberer poses the question: Was the "cosmopolitan socialism" of

the Jews who identified themselves with the Russian revolutionary movement devoid of any Jewish content, as has been claimed by historians? Was it merely the ideology of "frantic assimilationists", who sought to promote Russification in a socialist guise? . . Judging from what we know about the thoughts and actions of Jewish radicals, this was hardly the case. One only need recall the motives which led Akselrod, Tsukerman, Liberman, Zundelevich, Aptekman, Deich, Gurevich, and others to enter the "universal church" to realize that their cosmopolitanism was a transfiguration of their Jewishness rather than an assimilationist desire to conform with the norms and values of contemporary Russian society. Evidently, their "sincere assimilationism", as Iokhelson termed it, had nothing in common with Russification for the sake of social acceptability and professional advancement. They did not forsake their Jewish heritage to replace it with another form of cultural identity or ethnic belonging. What they sought can best be described as an abstract and futuristic idealism of assimilation qua emancipation in a denationalized and secularized democratic society, ideally of universal scope. Leaving the world of their childhood did not necessarily imply its total abandonment in one act of universal forgetfulness. For many this departure under the sacred halo of socialism was the next best solution to their own existential problems-a solution that was enormously attractive since it held out the utopian promise of the "genuine emancipation" of all Jews in a socialist republic of universal brotherhood devoid of national, religious, and social discrimination or even distinctions ... How closely this cosmopolitan socialism was related to their Jewishness has been shown in their adoption of a revolutionary career and/or their response to the anti-Jewish pogroms. ${ }^{22}$

In fairness to both Wistrich and Haberer, it should be noted that Haberer's focus is more eastward than that of Wistrich; none of the revolutionaries named above appears, even as a marginal figure, in either Revolutionary Jews from Marx to Trotsky or Socialism and the Jews. Further, their respective theses, though dissimilar, are not mutually exclusive.

It is intriguing that in his pantheon of Jewish socialists Wistrich does not choose to discuss those who were able to fuse Judaism or Jewish nationalism with socialism-with the exception of Moses Hess. He has taken upon himself the task of detailing the divergence of an affirmative Jewish movement, whether Diaspora or Palestine-based, from a commitment to socialism. The proverbial other side of the

\footnotetext{
${ }^{21}$ See Dmitri Volkogonov, Trotsky: The Eternal Revolutionary, trans. and ed. Harold Shukman (New York, 1995).

${ }^{22}$ Erich E. Haberer, Jews and Revolution in Nineteenth Century Russia (Cambridge, 1995), p. 259.
} 
coin-the convergence, as opposed to the simple collision, of Jewish collective identity formation with socialism - has been most assiduously examined by Jerusalem historians such as Jonathan Frankel and Ezra Mendelsohn, in the case of Eastern and East Central Europe, and by numerous scholars who have explored the career of Zionist socialism in Palestine and Israel, such as Derek Penslar, Anita Shapira, S. N. Eisenstadt, Israel Kolatt, Yonathan Shapiro, Deborah Bernstein, and Mitchell Cohen.$^{23}$ It is too simple to say that Wistrich is unable to square his own, unabashed Zionist faith with the reality on the ground-that it was often merged with some variety of socialism. Instead, it seems that Wistrich has a more general aversion to recognizing that Jews were able to embody several different identities simultaneously, even some that were apparently at odds with each other. In this he is not alone: in much of modern Jewish history there is a tacit understanding that because a person chose to belong to a certain political or religious group, one can assume all sorts of other things about the person-excluding the notion that the same individual might consider him- or herself a member of an opposing current at the same time. ${ }^{24}$ This perspective assumes that Jews were much more ideologically driven than they probably were. Primarily it has been the charge of a newer vintage of scholars, such as David Biale, Aron Rodrigue, David N. Myers, John Efron, Michael Brenner, Keith Pickus, Jeffrey Grossman, and David Brenner, to challenge the earlier monochromatic portrayal of Jewish spiritual and political allegiances. ${ }^{25}$

${ }^{23}$ Jonathan Frankel, Prophecy and Politics: Socialism, Nationalism, and the Russian Jews, $1862-$ 1917 (Cambridge, 1981); Ezra Mendelsohn, Zionism in Poland: The Formative Years, 1915-1926 (New Haven, Conn., 1981); Derek Penslar, Zionism and Technocracy: The Engineering of Jewish Settlement in Palestine, 1870-1918(Bloomington, Ind., 1991); S. N. Eisenstadt, Jewish Civilization: The Jewish Historical Experience in Comparative Perspective (Albany, N.Y., 1992); Yonathan Shapiro, The Formative Years of the Israeli Labour Party (London and Beverly Hills, Calif., 1976); Anita Shapira, Ha-ma'avak ha-nikhzav: 'Avodah 'Ivrit, 1929-1939 (The futile struggle: Hebrew labor, 1929-1939) (Tel Aviv, 1977), Land and Power: The Zionist Resort to Force, 1881-1948, trans. William Templer (New York, 1992), and Berl: The Biography of a Socialist Zionist, trans. Haya Galai (New York, 1984); Israel Kolatt, "The Organization of the Jewish Population of Palestine and the Development of Its Political Consciousness before World War I," in Studies in Palestine during the Ottoman Period, ed. Moshe Maoz (Jerusalem, 1984), pp. 211-45; Deborah Bernstein, The Struggle for Equality: Urban Women Workers in Prestate Israeli Society (New York, 1987); Deborah Bernstein, ed., Pioneers and Homemakers: Jewish Women in Pre-State Israel (Albany, N.Y., 1992); Mitchell Cohen, Zion and State: Nation, Class, and the Shaping of Modern Israel, 2d ed. (New York, 1993).

${ }^{24}$ See Jehuda Reinharz, Fatherland or Promised Land? The Dilemma of the German Jew, 18931914 (Ann Arbor, Mich., 1975).

${ }^{25}$ David Biale, Power and Powerlessness in Jewish History (New York, 1986); Eros and the Jews: From Biblical Israel to Contemporary America (New York, 1992); Gershom Scholem: Kaballah and Counter History (Cambridge, Mass., 1979); Aron Rodrigue, Images of Sephardi and Eastern Jewries in Transition: The Teachers of the Alliance Israelite Universelle, 1860-1939 (Seattle, 1993); Myers (n. 3 above); John Efron, Defenders of the Race: Jewish Doctors and Race Science in Fin-de-Siecle Europe (London and New Haven, Conn., 1994); M. Brenner (n. 13 above); Keith Pickus, "Jewish University Students in Germany: The Construction of a Post-Emancipation Identity" (Ph.D. diss., University of Washington, 1993); "German-Jewish Identity in the Kaiserreich: Observations and Methodological Considerations," Jewish History 9, no. 2 (Fall 1995): 73-91; Jeffrey Grossman, "The Space of Yiddish in the German and German-Jewish Discourse" (Ph.D. diss., University of Texas at Austin, 1992); Mark Gelber, "The jungjuedische Bewegung: An Unexplored Chapter in German-Jewish Literary and Cultural History," Leo Baeck Institute Year Book 31 (1986): 105-19; 
The single greatest drawback of Wistrich's magisterial study of Viennese Jewish history, The Jews in Vienna in the Age of Franz Joseph, is his tendency to see his subjects as members of only a single segment of the community at any one time. ${ }^{26}$ Nevertheless, as a chorus of reviewers has proclaimed, his weighty tome on Vienna's Jews is important and impressive. This adds to one of the strengths, as opposed to filling a lacuna, of modern Jewish historiography. Wistrich's book will join other renowned portraits of urban Jewish communities, such as the rendering of New York's Lower East Side by Moses Rischin and Irving Howe, William Fishman's study of London's East End, and Steven Zipperstein's compelling interpretation of the Jews of Odessa. ${ }^{27}$ The Jews of Vienna is, as well, a welcome complement to the work of Marsha Rozenblit, Steven Beller, and Harriet Freidenreich. ${ }^{28}$ A central question that occupies Wistrich here is, If one has and holds liberal values, how does one protect oneself when these are no longer operative in the larger world? Can a community survive through a nonchauvinistic separation from the majority culture? To what extent might an aggressive attempt at antidefamation assist a group in its quest for survival? Wistrich thoughtfully divides his comprehensive study into four major sections: the community, self-defense against antisemitism, the rise of Zionism, and culture and identity. Diverse manifestations of Jewish religious, political, and cultural streams emerge as integral themes. Yet a large question remains: Has he, as promised in his preface, addressed "in depth ... the nature of Jewish identity and self-definition, the impact of antiSemitism, and the role of Jews in Viennese culture and politics" (p. x)?

Without a doubt, Wistrich assumes a wider purview of Jewish culture than does Beller; his analysis of Jewish politics, too, is more fleshed-out than the able study of Freidenreich, which covers the period after the reign of Franz-Joseph. We are left, however, with a sizable volume which slights some important sides of Vienna's "Jewish identity and self-definition"-it remains, for the most part, in the realm of elites. We do not learn very much about the community's women and children, whose story might have been revealed in sources other than those Wistrich uses. Women must have been vitally affected when "the conflict between Josephinian modernization and traditional culture became particularly intense" (p. 17). Steven Lowenstein, Marion Kaplan, Claudia Prestel, Todd Endelman, and Susan Tananbaum offer models for this kind of Jewish social history. ${ }^{29}$ Moreover, although a

David Brenner, "Promoting the Ostjuden: Ethnic Identity, Stereotyping, and Audience in the German-Jewish Cultural Review Ost und West, Berlin, 1901-1923," (Ph.D. diss., University of Texas at Austin, 1993).

${ }^{26}$ Robert S. Wistrich, The Jews of Vienna in the Age of Franz Joseph (Oxford, 1990). Page references to this work are cited parenthetically in the text.

${ }^{27}$ Moses Rischin, The Promised City: New York's Jews, 1870-1914 (Cambridge, Mass., 1962); Howe, World of Our Fathers (n. 12 above); William Fishman, East End 1888: Life in a London Borough among the Laboring Poor (Philadelphia, 1988); Steven Zipperstein, The Jews of Odessa: A Cultural History (Stanford, Calif., 1986).

${ }^{28}$ Marsha Rozenblit, The Jew of Vienna, 1867-1914: Assimilation and Identity (Albany, N.Y., 1983); Steven Beller, Vienna and the Jews: A Cultural History (Cambridge, 1989); Harriet Freidenreich, Jewish Politics in Vienna, 1918-1938 (Bloomington, Ind., 1991).

${ }^{29}$ Steven Lowenstein, The Berlin Jewish Community: Enlightenment, Family and Crisis (New York, 1994); and The Mechanics of Change: Essays in the Social History of German Jewry (Atlanta, 
huge share of Vienna's Jews were working class and Yiddish speaking, we do not gain much of a sense of the mental or material universe of "the masses" (p. 21). Wistrich reports, for instance, that "Galician Jews established a whole network of Landsmannschaften in Vienna, providing welfare benefits, mutual aid, and social contacts to help the new immigrants" (p. 50). Even if this phenomenon were less formidable than its counterparts in Paris, London, and New York, it would merit more comment. The angle of approach is decidedly that of the more well-born and Germanically acculturated.

In his generally excellent treatment of Jewish protonationalism and Zionism, Wistrich tends to cordon off the "national" impulse from other motivations in the Jewish mind and soul that might have contributed to nationalist self-assertion. He finds it "curious" that "urbane cosmopolitan Jews like [Baron Maurice de] Hirsch and Edmond de Rothschild in Paris who stood in the vanguard of modern capitalism should have embraced a romantic precapitalist philosophy which regarded agriculture as the key to Jewish rehabilitation" (p. 78). It was not only these Jewish capitalists who prized such notions; after all, the outspoken antisemite Henry Ford, who did so much to change the landscape of America, saw his preindustrial "Greenfield Village" as an ultra-American model. ${ }^{30}$ Wistrich furthermore argues that "The Baron Hirsch Foundation of Vienna" was not "just another 'charitable' or 'philanthropic' institution but a kind of development agency, a pilot plant for relieving the economic poverty and cultural backwardness of Galician Jewry" (p. 78). Does not charity also come into play here, and in the Zionist movement proper, despite the claim of its proponents that it transcended the charitable instincts of the Jews (p. 307)? Indeed, the development of modern social welfare, and Jewish charity work in particular, shows that "occupational reconstruction" (p. 79) was very much a part of the agenda of social reform-minded Jews from the mid-nineteenth century onward. In short, nationalism, philanthropy, and charity are not mutually exclusive categories (pp. 82-86). Although the Jewish National Fund, founded by Vienna's Johann Krementzky, was styled as Zionism's treasury toward building Jewish self-help in Palestine (pp. 375-76), it may help to ask: To what extent was its success dependent on the Jewish tradition of Tzedakah, or giving to charity to promote justice?

For the most part, Wistrich evinces a keen detachment from his subject, as in his evaluation that it was an "anomaly that in an age of growing democratization in Austrian politics (the five-florin artisans and small traders had been enfranchised

1992); Marion Kaplan, The Making of the Jewish Middle Class: Women, Family, and Identity in Imperial Germany (New York and Oxford, 1991); Claudia Prestel, Juedisches Schul- und Erziehungswesen in Bayern, 1884-1933: Tradition und Modernisierung (Gottingen, 1989), and "Bevoelkerungspolitik in der juedischen Gemeinschaft in der Weimarer Republik: Ausdruck juedischer Identitaet?" Zeitschrift fuer Geschichtswissenschaft 41 (1993): 685-715; Todd Endelman, Radical Assimilation in English Jewish History (Bloomington, Ind., 1990); Susan Tananbaum, "Generations of Change: The Anglization of Russian-Jewish Immigrant Women in London, 18801939” (Ph.D. diss., Brandeis University, 1991).

${ }^{30}$ See William Adams Simonds, Henry Ford and Greenfield Village (New York, 1938); Reynold M. Wik, Henry Ford and Grass Roots America (Ann Arbor, Mich., 1972), pp. 203-4. On Ford's antisemitism, see Albert Lee, Henry Ford and the Jews (New York, 1980); Leonard Dinnerstein, Antisemitism in America (New York, 1994), pp. 81-83. 
in general and local elections in Vienna since 1882) the Jewish community remained more oligarchical in its internal tax and voting structure than the wider community" (pp. 91, 341-42). It is not often explicitly stated in works of Jewish history that "in spite of a multitude of teaching establishments including several kindergartens, a Talmud Torah school, a Beth Hamidrash (1862), and a Jewish theological college (1893), religious education made little impact on the mass of Viennese Jews" (p. 129). He also notes the "deep and bitter irony" that "PanGermanism in Austria," which accounted for virulent antisemitism, "was partly a creation of liberal-nationalist Jews" (p. 209).

As in his earlier works, Wistrich's portraits of outstanding Jewish personalities in the Viennese milieu, such as Adolf Jellinek (1821-93), Moritz Guedemann (1835-1918), Adolf Fischof (1816-93), Joseph Bloch (1850-1923), Theodor Herzl (1860-1904), and Martin Buber (1878-1965), are exemplary. Interestingly, he praises Guedemann's scholarship for "reconstructing the internal life of medieval Franco-German Italian Jewry by approaching history from below and examining Jewish customs, manners, superstitions, morals, language, and literature in terms of the society in which they lived" (p. 124). This view "from below" is what is most absent in Wistrich's oeuvre. Still, Wistrich deftly connects myriad personalities without losing touch with his main thread: What did they mean to the communal existence and consciousness of Viennese Jewry? Wistrich's Jews of Vienna should be taken as one of the most authoritative guides to complicated personalities like Nathan Birnbaum (1864-1937), Karl Kraus, Sigmund Freud, and Otto Weininger, who are something of a Rorschach test for many scholars. Here too Wistrich's focus on their impact on their contemporaries is always on solid footing, and often remarkably perceptive: "The literary activity of the Viennese and Galician maskilim did not exercise a noticeable direct influence on the Jews of Vienna, who could not have constituted at any time more than a minority of the subscribers to their periodicals. Nevertheless, the spiritual leaders of Viennese Jewry-[Isaac Noah] Mannheimer, Jellinek, and Guedemann—did seek to encourage the love of the sacred language [Hebrew] and the spread of Hebrew culture, seeing it as being complementary, rather than in contradiction to the spirit of German Wissenschaft and Bildung" (p. 138). The influence of Rabbi Bloch apparently spread beyond the Jewish environs, as his lectures were "distributed in thousands of copies, reprinted in the socialist press, and helped to dissuade Viennese workers from being manipulated by anti-Semitic agitators" (p. 280).

Wistrich also succeeds masterfully, in many instances, at juxtaposing the myths and cold facts of Jewish existence: "At the end of the nineteenth century the material prosperity of Viennese and Austrian Jewry as a whole appeared in the eyes of many Gentiles as an indisputable fact. These legendary riches were to a large extent mythical. Jewish wealth and power was invariably exaggerated by anti-Semitic demagogues who ignored the far greater assets and influence of the great feudal landowners as well as the poverty of the mass of Austrian Jewry" (pp. 165, 29496). On Viennese antisemitism Wistrich does not attempt to revise the widely accepted work of scholars such as John Boyer, Jacob Toury, and Peter Pulzer, yet his incorporation of their theses and his contextualization of the work of scores of 
other scholars and commentators in both primary and secondary literature are superb. ${ }^{31}$

Wistrich's unique addition to this literature is a subtle gauge of the Jewish response, such as his comment that for all of Rabbi Jellinek's "bitterness at the Berlin [anti-Semitic] movement, [he] did not abandon his faith in the superiority of German culture. In April 1881 he seemed reassured by the fact that only 255,000 Germans had signed the anti-Semitic petition to Chancellor Bismarck, calling for the revocation of Jewish equality! Adolf Stoecker's defeat in Berlin by the distinguished liberal physician Rudolf Virchow during the 1884 Reichstag elections appeared to salvage German honour in his eyes" (pp. 250-51). Jellinek's love of Austria, like that of most of his coreligionists, was steadfast (pp. $256 \mathrm{ff} ., 298$ ). This did not, however, translate into "passive resignation" on the part of Viennese Jewry; their outspoken liberals "did not simply despair, accept their fate with equanimity, or else flee from reality into an idealized image of the past" (p. 267). One could even find "militancy" on the pulpit (p. 286). But responses to antisemitism by Jellinek and others were always within the bounds of respectability (p. 290). Specifically, the "Defence Bureau" of the "Austrian Israelite Union" was able to discern that "the defence of Jewish rights must be extended to the mass of Jews in the Austrian provinces who were physically more exposed than their coreligionists in the Imperial capital"; the Bureau "did not interpret its work in a narrow, formalistic manner nor was it confined to simply repelling anti-Semitic attacks in Vienna" (p. 336).

Wistrich is at his best in detailing the rise of the Zionist movement in Viennain particular that of the student society Kadimah, which would "supply the backbone of Theodor Herzl's support in the mid-1890s, providing a well-tested group of devoted cadres that enabled him to build the first centrally organized Zionist movement" (pp. 349, 372) dedicated to the "regeneration of the Jewish nation" (p. 360). The author disentangles the complex encounter of this party and its successors with the existing Jewish communal structures, which did not easily give way (pp. 362 ff.). Wistrich reports that "by a curious paradox, the movement to halt the denationalization of Jewry found itself borrowing its expressive forms and modes of behaviour from the German culture against which it reacted" (p. 363). Dueling, commers-feste, and drinking would have a different significance for the small minority of Jewish nationalists, but these facets were nevertheless obligatory. Again, Wistrich is formidable in exploring the concept of agency in the Jewish world: he shows precisely how Kadimah's influence was well beyond its meager numbers, in part because of its extremely popular "Maccabean functions" (p. 365). The early stresses and strains of the movement are laid bare, such as when Theodor Herzl

\footnotetext{
${ }^{31}$ John W. Boyer, Culture and Political Crisis in Vienna: Christian Socialism in Power, 1897-1918 (Chicago, 1995), and Political Radicalism in Late Imperial Vienna: Origins of the Christian Social Movement, 1848-1897 (Chicago, 1981); Jacob Toury, Soziale und politische Geschichte der Juden in Deutschland, 1847-1871: Zwischen Revolution, Reaktion und Emanzipation (Dusseldorf, 1977), and Die politische Orientierung der Juden in Deutschland: Von Jena bis Jena (Tubingen, 1966); Peter Pulzer, The Rise of Political Anti-Semitism in Germany and Austria, rev. ed. (Cambridge, Mass., 1988).
} 
laments his quarrels with Nathan Birnbaum, who had attempted to ignite Jewish nationalism years before Herzl: “'We haven't got the country, and they already want to tear it apart"" (p. 410). Birnbaum, with "his various mutations" seeming to "embody many of the central problems of the Jewish national renaissance in Central and Eastern Europe" (p. 385), would later turn from "political to cultural Zionist, from Pan-Judaist and Yiddishist to Agudas Yisroel" in trying to master "the mystery of Jewish survival" (pp. 418-19).

It is well known, that Zionism in Central Europe did not have much of a following at the fin-de-siecle. Wistrich shows the deep sources of the discomfort, if not animosity, toward the movement: "Liberal critics in Vienna, as elsewhere, contended that Zionism stood in open defiance to the whole trend of historical evolution which was tending towards assimilation and the fusion of the Jewish minority with the surrounding nations. Liberals did not necessarily deny the existence of a 'Jewish Question' in Vienna, in the Dual Monarchy, or in Europe as a whole. But they generally felt that Zionism would merely aggravate anti-Semitism instead of providing a cure" (p. 460). Certainly the leading rabbi, Guedemann, was not alone in distrusting Zionism because of his "tenacious refusal to allow the anti-Semites to deny his 'inalienable right' to German nationality" (p. 481). Nor was there much support from the left of the political spectrum, as Jewish socialists "tended to regard Zionism as a reactionary and artificial attempt to separate Jews from other peoples on the basis of a non-existent Jewish "nationality"' (p. 485). Jewish Marxists denounced Zionism as "the class ideology of the Jewish bourgeoisie and the economically declining Mittelstand in the Austrian provinces" (p. 486). Despite these well-reasoned arguments, the movement did take hold, in part due to the "willingness to recognize the educational value of the Zionist movement and its contribution towards the organization of Jewish self-help" (p. 468). Wistrich deftly ties threads between culture and politics, such as in his estimation of Karl Kraus's appellation for Theodor Herzl, "Der Koenig von Zion," on the latter's reputation in Vienna (pp. 491-93).

The last section of The Jews of Vienna is titled "Culture and Identity," although by no means does this mark the first appearance of this issue. "Culture," here, refers mostly to literature and to a lesser extent to the psychoanalytic movement, which not coincidentally would have a disproportionately immense impact on the literary scene and its interpretation.

In this city renowned for its superficial gaiety and Strauss waltzes, personal traumas and collective anxieties fused to produce such diverse movements as psychoanalysis, Austro-Marxism, Zionism, anti-Semitic mass parties, logical positivism, and the Viennese secession which were to change the face of the twentieth century. Jews by virtue of their special place in the urban intelligentsia stood in the forefront of this fermentation and change. Doubly alienated, both as intellectuals and Jews, from other sectors of the ruling elite, their avant-garde role in the development of radically new paradigms, myths, and cultural values was frequently decisive. Not surprisingly, the crisis of liberal rationalism and the disillusionment with politics that characterized the Austrian fin-desiecle as a whole was experienced by Jewish intellectuals with particular intensity; for the defeat of political liberalism had coincided with the rise of a triumphant mass anti- 
Semitism that threatened their mental equilibrium and the very foundations of Jewish existence. The modern cultural crisis that overtook Austria thus became inextricably bound up with fundamental questions involving Jewish identity in the personal and collective sense. (P. 499)

In his reading of figures such as Weininger, Karl Kraus, Sigmund Freud, Arthur Schnitzler, Stefan Zweig, Hugo von Hofmannsthal, Richard Beer-Hofmann, Gustav Mahler, Arnold Schoenberg, and Joseph Roth, Wistrich is an estimable guide for an audience wishing to locate them in the contemporary Viennese milieu. To borrow a term from David Sorkin's analysis of Jewish Berlin in the years before the fin-de-siecle, Wistrich shows that these men (women are hardly ever mentioned) constituted something of an "invisible community"; in so doing he explores the myriad connections between Freud and Schnitzler and Herzl (pp. 578, 589), Buber and Hofmannsthal and Zweig (pp. 641-42, 649-51), and the more obvious relationship of Schoenberg to Mahler (pp. 629-30). Although looking at Weininger in retrospect might inspire shock or an attempt to see his writing as "a simple expression of personal pathology," the author adroitly advises that "such an interpretation overlooks, however, the long cultural conditioning that made Weininger's antiSemitic paroxysms possible and it ignores the socio-political context of fin-desiecle Vienna" (p. 535).

For a number of reasons those seeking to recapture and understand the larger cultural scene of Vienna will continue to consult the work of Carl Schorske, William McGrath, and David Luft; and on its Jewish aspect, the more specialized studies of Dennis Klein and Steven Beller-which, as opposed to Wistrich's sobriety, offer more distinctive theses about the connections between "Jewishness" and the burst of cultural creativity on the part of Vienna's Jews. ${ }^{32}$ Nor will his work replace the solid political and demographic treatments of Freidenreich and Rozenblit. But as a readable book for academics and the more scholarly general public, Wistrich's description and analysis is superior and better grounded than those of, say, William Johnston and Fredric Grunfeld. ${ }^{33}$ The Freud that appears here, for instance, is not nearly as much a creation of the author's inner demons as is that of John Murray Cuddihy or Peter Gay. ${ }^{34}$ As opposed to an abject rejection of his "Galician Jewish background," Wistrich shows how Freud's feelings about his origins are deeply "ambivalent" (pp. 539, 575). In following the lead of Dennis Klein's

${ }^{32}$ Carl Schorske, Fin-de-Siecle Vienna: Politics and Culture (New York, 1979); David Luft, Robert Musil and the Crisis of European Culture, 1880-1942 (Berkeley and Los Angeles, 1980); William J. McGrath, Freud's Discovery of Psychoanalysis: The Politics of Hysteria (Ithaca, N.Y., 1986); Dennis Klein, Jewish Origins of the Psychoanalytic Movement (New York, 1981); Beller; John Murray Cuddihy, The Ordeal of Civility: Freud, Levi-Strauss and the Jewish Struggle with Modernity (New York, 1974).

${ }^{33}$ Fredric Grunfeld, Prophets without Honour: A Background to Freud, Kafka, Einstein and Their World (New York, Tokyo, and London, 1995); William Johnston, The Austrian Mind (Berkeley, 1972). Grunfeld's interpretation, recently reissued with an excellent introduction by Michael Brenner, is one of the best popularized accounts.

${ }^{34}$ Murray; Peter Gay, Freud, Jews and Other Germans: Masters and Victims in Modernist Culture (New York, 1978). 
(unduly undervalued) Jewish Origins of the Psychoanalytic Movement, the author resists the de-Judaization of Freud, while at the same time showing that his Jewishness was of a supremely secular-humanistic flavor and that psychoanalysis was indeed a "Jewish movement" despite its founder's greatest hopes for its universal approval and application (pp. 554-55, 565 ff., 578, 586).

If there is one strand that ties Wistrich's Jewish tapestry together it is the shared belief "in the priority of culture over politics" (p. 644), a phrase the author employs in his discussion of novelist Stefan Zweig. Even the founder of Zionism, Theodor Herzl, in his utopian novel Altneuland, saw culture as the far more critical determinant in men's lives, to the point that "a society of men" could cohere even without the framework of a nation-state. In his book Weekend in Munich: Art, Propaganda and Terror in the Third Reich, Wistrich turns to the Nazi order, which saw art-in the narrow sense-as unquestionably subservient to the interests of the German state. ${ }^{35}$ This volume grew out of the author's consultation for the documentary film Good Morning, Mr. Hitler! produced for Channel 4 in England. The methods Wistrich uses in this book, as opposed to his Jews of Vienna, casts in sharp relief the predisposition he earlier brought to bear on the study of antisemitism versus the study of Jewish history. The "aim" of Weekend in Munich, Wistrich writes, "is simultaneously to convey some of the visual appeal of Nazism while deconstructing its meanings and deflating its pretensions" (p. 7). This does not herald a "linguistic turn" in his scholarship a la Foucault or Derrida. It does indicate, however, that Wistrich is not untouched by historiographic debates and ongoing developments. His intention is to "deconstruct" the "appeal" of Nazism, which he perceives as maintaining some kind of hold on contemporary popular consciousness and as contributing to an unhealthy "fascination" for the regime even on the part of scholars, such as Joachim Fest (p. 12).

Although Weekend in Munich lacks the depth of the essays contained in the volume Degenerate Art, which accompanied the exhibit that toured the United States in 1990-91, this is an estimable one-volume treatment, richly and effectively illustrated, on the problem of art and culture in the Third Reich. ${ }^{36}$ The event that inspired the documentary was the discovery of a film made in 1939, which serves as the focal point for this book.

The images in this book originate from a spectacular Nazi pageant called the Day of German Art, which was held in Munich during the weekend of 14-16 July 1939. It was to be the third and last time this popular festival would be celebrated in the Bavarian capital, though the art exhibitions previously linked with it continued through most of the war years.

What makes this particular event so interesting is that a remarkable film record of it was recently recovered, made in 1939 by a talented amateur film-maker, Hans Feierabend. This film is in brilliant color and the unique images it contains are reproduced here for the first time. They were not subjected to the usual stage management and

${ }^{35}$ Robert S. Wistrich, Weekend in Munich: Art, Propaganda and Terror in the Third Reich (London, 1995). Page references to this work are cited parenthetically in the text.

${ }^{36}$ Stephanie Barron, ed., "Degenerate Art": The Fate of the Avant-Garde in Nazi Germany (New York, 1991). 
manipulative techniques of the Nazi propaganda machine. Hence they provide us with a different angle of vision on the Third Reich, one which is deceptively normal, relaxed and disarming.

The effect of the colour is similar to being suddenly taken on a psychedelic trip into a sinister, traumatic past only to be confronted by unexpected visions of innocence and joy. It is a disconcerting and in some ways even a shocking experience. (P. 10)

At the center of the Nazi effort to redefine art was the destruction of all that was defined as un-German, Jewish, Bolshevik, or "decadently modern." Furthermore, it was ruled subversive even to "question, criticize, evaluate or analyse art" (p. 17). Echoing the work of George Mosse in Nazi Culture and elsewhere, Wistrich convincingly shows that "art was assigned a key role in the propagation of ideology and of politics as a mass spectacle in the Third Reich" on a number of levels (pp. 18-19). ${ }^{37}$ His intermingling of images from the film and quotes from those who were there is striking; his explanations are terse and spare in this section (pp. 97143). Even though the book purports to be narrow, with its microscopic attention to an extraordinary "home movie," it brings the legacy of fascist aesthetics nearly up to the present, including a lucid analysis of music in "skinhead subculture" (pp. 148-50) and "the current crop of xenophobic nationalists," including Joerg Haider and Vladimir Zhirinovsky (pp. 156-57).

Wistrich's goal-to discover an "essence" of "the Nazi phenomenon"-is not the motivation of many other academic historians; at least, most would not admit it in an age when postmodernists argue that entities such as essences are always chimeras. The author contends that one finds "irrationality" when peering into the heart of Nazism (p. 23). Without meaning to suggest any sort of equivalence between Jews and Nazis, which has tragically become a staple of half-baked political discourse,$^{38}$ one might wonder, Does that mean that rationality lies at the core of the Jewish experience? Is being Jewish about rationality and respect for an allencompassing sense of moral order? On the contrary, might it be said that there is something deeply irrational about the Jews' belief, even in the face of great adversity and enmity, that they could somehow "win" acceptance in both the corporate and individual sense? Some years ago the great Jewish historian Yosef Yerushalmi called for his colleagues to write a history of "Jewish hope." It was an excellent challenge and admonition, because most Jewish historiography, including the work of Wistrich, had taken Jewish hope for granted. In The Shaping of Israel: Memory, Myth, and National Identity, Wistrich's most recent edited volume, however, Wistrich has sought to examine the basis of Jewish hope and dreams in relation to the Zionist project. ${ }^{39}$

Part of the reason why this may be seen as a welcome turn in the Wistrich oeuvre is the evidence that he is evolving as a scholar. Here he looks at Jewish nationalism

\footnotetext{
${ }^{37}$ George Mosse, Nazi Culture: Intellectual, Cultural and Social Life in the Third Reich (New York, 1966), pp. 25-32, 57-64, 135-40, 162-65, and "Beauty without Sensuality," in Barron, ed., pp. 25-31.

${ }^{38}$ See Alain Finkielkraut, Remembering in Vain: The Klaus Barbie Trial and Crimes against Humanity, trans. Roxanne Lapidus with Sima Godfrey (New York, 1992).

${ }^{39}$ Wistrich and Ohana, eds. (n. 5 above), intro., pp. vii-xiii.
} 
in a way that is not completely different from his approach to non-Jewish nationalism and other political movements. Again he has taken on the role of editor with an eye toward inclusiveness. Moreover, in this volume he turns "to dissect and deconstruct" the "multiplicity of meanings" 40 in discrete phenomena connected to the emergence of Zionism and the rise of the State of Israel. He noticeably strays from, or has revised his earlier assertion, a la Gertrude Himmelfarb and Theodore Hamerow, that "Contemporary post-modernism, with its assault on objectivity, abstraction, rational thought and systematic analysis, has some disturbing, if nonideological, echoes of these fascist premises." ${ }^{41}$ In his essay "Theodor Herzl: The Making of a Political Messiah," Wistrich employs a critical perspective which until this point had been absent from his work in Jewish history. ${ }^{42}$ He approaches the more irrational well-springs of Jewish politics in the modern era, which nicely complements Yael Zerubavel's essay "The Land of Israel: A Phenomenology of Place," Eric Cohen's "Israel as a Post-Zionist Society," and Zeev Tshahor's "Ben Gurion as a Myth-Maker." In Weekend in Munich, Wistrich surmises that the Nazis had a "predilection for the mythical and the irrational" (p. 160). The question may be raised, Which community of affinity is immune to such a predilection?

This is not to say that Wistrich would be fully at home with Hayden White's notion that "the historical past is populated above all by human beings, who, besides being acted on by 'forces,' are acting with or against such forces for the realization of life projects that have all the drama and fascination, but also the meaning (Sinn), of the kinds of stories we encounter in myth, religious parable, and literary fiction." ${ }^{43}$ Nevertheless he seems to be nearing the kind of analyses offered by such prescient observers as Gershom Scholem, Amos Funkenstein, Sander Gilman, George Mosse, and Yosef Yerushalmi, who have recognized the importance, if not the primacy, of "counterhistorical" currents in Jewish history. ${ }^{44}$ The range and evolution of the work of this not-yet-old scholar indicates his openness and the healthy pluralism of his own outlook. And if one genuinely tends to look favorably on historians who self-consciously attempt to inhabit and influence the world beyond academe, ${ }^{45}$ Wistrich's star shines all the more brightly.

\footnotetext{
${ }^{40}$ See Luke Holland, "Foreword," in Wistrich, Weekend in Munich, p. 9.

${ }^{41}$ Wistrich, Weekend in Munich, p. 160.

${ }^{42}$ Robert S. Wistrich, “Theodor Herzl: The Making of a Political Messiah," in Wistrich and Ohana, eds., pp. 1-37.

${ }^{43}$ Hayden White, "Ricoeur's Philosophy of History," in his The Content of the Form: Narrative Discourse and Historical Representation (Baltimore and London, 1992), p. 175.

${ }^{44}$ Amos Funkenstein, Perceptions of Jewish History (Berkeley and Los Angeles, 1993); Sander Gilman, Jewish Self-Hatred: Anti-Semitism and the Hidden Language of the Jews (Baltimore, 1986); Yosef Yerushalmi, Zakhor: Jewish History and Jewish Memory (Seattle, 1982), and Freud's Moses: Judaism Terminable and Interminable (New York, 1991).

${ }^{45}$ See Novick (n. 2 above), pp. 520-21.
} 